\title{
Antecedents of Word of Mouth Behaviour among Female Grocery Shoppers in Iran
}

\author{
Patricia Harris*, Kingston Business School \\ Nasim Alsadat Khatami, Kingston Business School \\ *email - harris@kingston.ac.uk
}

\begin{abstract}
Purpose: This paper reports on research on the antecedents of Word of Mouth (WOM) behavior among Iranian women in the context of grocery shopping.

Design/methodology/approach: Using a survey instrument, we empirically test the conceptual model of De Matos and Rossi (2008).
\end{abstract}

Findings: We find support for the model and find satisfaction, commitment, loyalty, trust, perceived value and quality to be significant antecedents of WOM. Commitment is found to be the most significant predictor of WOM.

Research limitations/implications: We examine only factors affecting the initiation of positive WOM; future research should examine also drivers of negative WOM. Our sample consists of female shoppers at Tehran branches of one grocery retailer. There is scope to extend the research to shoppers of other grocery retailers and to other parts of Iran.

Practical implications: Our findings provide useful insight for practitioners in identifying the relative importance of drivers of WOM. Our research suggests that satisfaction is the weakest predictor of WOM, and therefore it is dangerous for grocery retail managers to rely on customer satisfaction metrics as indicators of WOM initiation.

Originality/value: Our research appears to be the first study of WOM's antecedents in Iran and also the first study of WOM in the context of Iranian grocery retailing, a sector which is both fast growing and under-going structural change.

Keywords: Word of mouth; consumer behaviour; grocery retailing; Iran

\section{Introduction}

Word of Mouth (WOM) continues to attract the attention of academic and practitioner researchers alike. However, despite this large body of research, very little is known about how WOM operates in Iran, a country where WOM is believed to have considerable influence and importance. Research which has been conducted on WOM in Iran has focused on the 
outcomes of WOM and, as a result, little is known about its antecedents. We seek to address this knowledge gap through a study of the antecedents of WOM. We conceptualize WOM as the focal construct of our research, rather than as a driver of other behavioural constructs such as purchase intention, and conduct an examination of its antecedents. Our study makes a contribution to both theoretical and managerial understanding of how WOM is created. In addition, we contribute to the understanding of WOM in Iran by setting our research in a context, Iranian grocery shopping, which is growing in size and importance within the Iranian economy. Our research focuses on traditional, face-to-face WOM; while electronic WOM (eWOM) has grown significantly in importance in recent years and has been the subject of much recent research (see Cheung and Thadani (2012) for a review) face-to-face WOM is still more prevalent than e-WOM and is considered to be more influential (Kimmel and Kitchen, 2014).

WOM can be defined as "informal communications directed at other consumers about the ownership, usage, or characteristics of particular goods and services and/or their sellers" (Westbrook, 1987, p.261) and is believed to have more influence on consumers' purchase decisions than non-personal communication tools (Magnold, 1987). Moreover, research shows that in addition to the significant impact of WOM on the formation of consumers' attitudes, positive WOM can reduce the risk associated with product or service purchasing (Shirsavar, Gilaninia and Almani, 2012).

Godes and Mayzlin (2004) note that WOM differs from traditional marketing tools in its ability to function as both a consequence of sales (consumers talking about something they have purchased) and also an antecedent of sales (consumers talking about a product and subsequently purchasing it). Building on this dual conceptualization, Jalilvand, Esfahani and Samiei (2011) posit that WOM creates a 'positive feedback mechanism' (p. 43) where increased WOM is associated with increased sales, which then leads to further WOM and further sales.

WOM is considered to be particularly important as a risk reducer in the context of services due to their experiential and intangible nature (Murray, 1991). In the retail sector, Higie, Feick and Price (1987) demonstrate that WOM is an effective communication tool in marketing strategy. Brown, Barry, Dacin and Gunst (2005) note that in retail, WOM might include mentioning or favorably recommending a store to others or telling others that you admire a store's quality. Higie, Feick and Price (1987) suggested that around $40 \%$ of retailers' customers were influenced by recommendation (i.e. WOM) in their purchase decision.

WOM's impact in the context of grocery shopping has been studied for a considerable time; according to Beal and Rogers (1957, cited in Ennew, Banerjee and Li, 2000) the most effective communication tool in convincing women to try a new grocery retailer is recommendations received from others. Urbany, Dickson and Kalapurakal (1996) find WOM to result in increased awareness of price promotions and to be 'a significant means of communication in the grocery market.'(p.101). Ennew, Banerjee and Li (2000) show that the influence of information received by WOM is seven times greater than the influence of magazine or newspaper advertisements in persuading women to choose a grocery retailer.

WOM is of importance in Iran as Iranians are believed to be particularly distrustful of paidfor communications and are as a result heavily reliant on WOM for information about products and services (Mohammadian and Shafiha, 2008). WOM activity in Iran has been researched in the context of banking (Ashtiani and Iranmanesh, 2012; Shirsavar, Gilaninia 
and Almani, 2012), automobile purchasing (Jalilvand and Samiei, 2012a), tourism (Jalilvand and Samiei, 2012b) and mobile telephony (Mosavei and Ghaedi, 2011). However, there would seem to be a knowledge gap in that WOM has not been researched in the context of the Iranian grocery market. As noted above, the powerful effect of WOM in the grocery sector has already been demonstrated outside Iran in many studies and therefore it seems appropriate to build on existing knowledge of WOM in Iran by investigating its effect within the Iranian grocery sector.

The retail grocery sector is one of the major components of Iran's economy with a value in 2011 of $£ 35.5$ billion. Small grocery retailers accounted for around 85\% of total grocery sales, suggesting a highly fragmented market (Euromonitor, 2013). Despite the dominance of traditional, small, independent outlets, the Iranian grocery sector is starting to evolve and modernize (Euromonitor, 2013). Two state-owned chains, Refah (160 shops across Iran) and Shahrvand (25 shops in Tehran) have been operational since the mid 1990's and were joined in 2009 by the first hypermarket, Hyperstar, which was a joint venture between Dubai based MAF Holding and Carrefour, the latter having a 25\% stake (Keller, 2009). As of 2013, there are three Hyperstar branches in Iran - in Tehran, Shiraz and Isfahan (Hyperstar Iran, no date).

The evolution of the Iranian grocery sector and the development of Western-style stores are causing the Iranian consumer to be faced with a rapidly changing grocery shopping landscape. Given the importance of WOM in Iran, as noted above, it seems likely that WOM will be used to navigate this rapidly changing retail landscape and help the consumer decide where to shop for groceries. This would seem, therefore, to be a good time to examine WOM within the Iranian grocery sector. In particular, we believe that it is important to begin such an examination by investigating the drivers or antecedents of WOM in order to provide useful managerial insight into how WOM might best be initiated.

\section{Conceptual Framework and Hypotheses}

The literature on the initiation of WOM suggests that its antecedents are satisfaction, loyalty, quality, commitment, trust and perceived value. De Matos and Rossi (2008) incorporated these constructs into the model of WOM antecedents shown in Figure 1. Their meta-analysis found positive relationships between each of the constructs shown in Figure 1 and WOM. This forms the basis of our research, conceptualising WOM as the focal construct rather than as a driver of other constructs such as purchase intention. The model provides a comprehensive platform on which to conduct a preliminary examination of WOM in the Iranian grocery sector, enabling us to examine the effect of each potential antecedent in isolation through measurement of the bivariate relationships. 
Figure 1: Conceptual Model

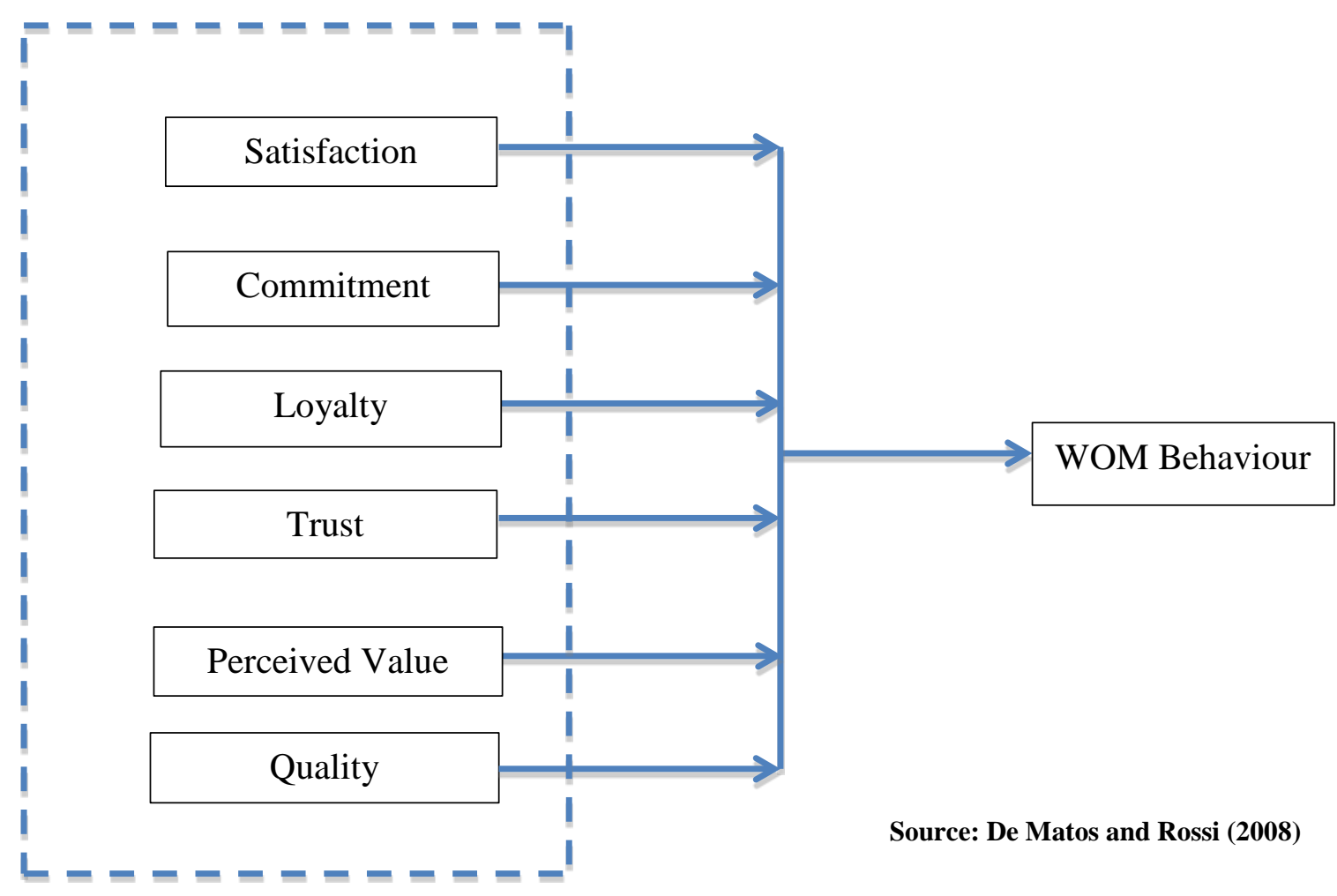

Although there is some evidence to the contrary (e.g. Arnett, German and Hunt, 2003; Reynolds and Beatty, 1999) there is widespread support for the view that satisfaction is an antecedent of WOM. Wangenheim and Bayón (2007) note that 'there is no shortage of research linking customer satisfaction to WOM' (p. 235) and describe customer satisfaction as the central WOM-affecting construct. This leads us to propose the following hypothesis:

H1: Satisfaction has a significant positive effect on WOM initiation among female grocery shoppers in Iran.

Hennig-Thurau, Gwinner and Gremler (2002) find that commitment has a strong, positive, direct effect on WOM while Heitmann, Lehmann and Hermann (2007) find that commitment is positively related to both the intensity and the valence of WOM. Brown et al. (2005) also found commitment to be an antecedent of WOM and argued that customers who are committed to a company, even when they experience a lower satisfaction level with the company's products or services, are likely to spread positive WOM to support their positive attitude towards and strong identification with the company. On the basis of this evidence, the following hypothesis is proposed:

H2: Commitment has a significant positive effect on WOM initiation among female grocery shoppers in Iran.

The relationship between loyalty and WOM has been conceptualised in two main ways: WOM as a component or outcome of loyalty, and loyalty as an antecedent of WOM. Although the former approach has been widely taken (Jones and Sasser, 1995; Sirdeshmukh, Singh and Sabol, 2002; Zeithaml, Berry and Parasuraman, 1996), de Matos and Rossi (2008) considered there to be sufficient evidence for loyalty as an antecedent of WOM. Dick and 
Basu (1994) suggested that customer loyalty might lead to the initiation of WOM, and evidence to support this was found by Carpenter and Fairhurst (2005) and by Sichtmann (2007). Support for the view that loyal customers are likely to spread positive WOM (Wangenheim, 2005) leads us to propose the following hypothesis:

H3: Loyalty has a significant positive effect on WOM initiation among female grocery shoppers in Iran.

Sichtmann (2007) found trust to have a significant effect on consumers' WOM behavior while Ranaweera and Prabhu (2003)'s research found trust to be as important as satisfaction in the initiation of WOM. Kim, Kim and Kim (2009) examined the relationship between trust and WOM in the context of recovery after service failure, and found that trust had a positive effect on WOM. Additionally, they found support for trust acting a mediator between satisfaction with service recovery and WOM. On the basis of this evidence we propose:

H4: Trust has a significant positive effect on WOM initiation among female grocery shoppers in Iran.

McKee, Simmers and Licata (2006) argued that customers who perceive they have received higher value from an organisation are provided with an incentive to support the organisation through exhibiting behaviours, such as WOM, which reciprocate the value with which they have been provided and demonstrate their attachment. They found support in their research for the strong, positive effect of perceived value on WOM. Lee, Yoon and Lee (2007) examined the relationship between perceived value and WOM in the context of tourism, and found a significant, positive effect. Hartline and Jones (1996) examined the effect of quality and perceived value on WOM; both were found to have positive effects on WOM, though perceived value had the stronger effect. Additionally, support for the positive effect of service quality on WOM is provided by the work of Harrison-Walker (2001), Bloemer, de Ruyter and Wetzels (1999), Zeithaml, Berry and Parasuraman (1996) and Boulding, Kalra, Staelin and Zeithaml (1993). We find support, therefore, to follow de Matos and Rossi (2008) in hypothesizing:

H5: Perceived value has a significant positive effect on WOM initiation among female grocery shoppers in Iran.

H6: Service quality has a significant positive effect on WOM initiation among female grocery shoppers in Iran.

\section{Method}

\section{Instrument Development}

To test the research model we collected data by means of a self-administered survey instrument in two sections. Section one measured the research model's constructs using seven-point Likert scale ("Strongly agree=7/Strongly disagree=1"). All measurement items and the scales used in this study are presented in Table 1.

Section two of the instrument comprised 13 questions which captured demographic and income data plus information on respondents' grocery shopping behaviour. The instrument 
was translated from English to Persian and a pilot test was conducted with seven female shoppers to confirm the validity of the translated questionnaire. Lee, More and Cotiw-an (1999) see pilot testing is an appropriate method of verifying a translation and checking the internal validity of a survey instrument. The pilot also allowed the adequacy of instructions to respondents to be evaluated. Pilot interviews results revealed the need for some minor changes in wording and layout, however the results showed that there were no significant problems with the instrument and that the questions were clear and understandable to respondents. 
Table 1: Measurement Scales

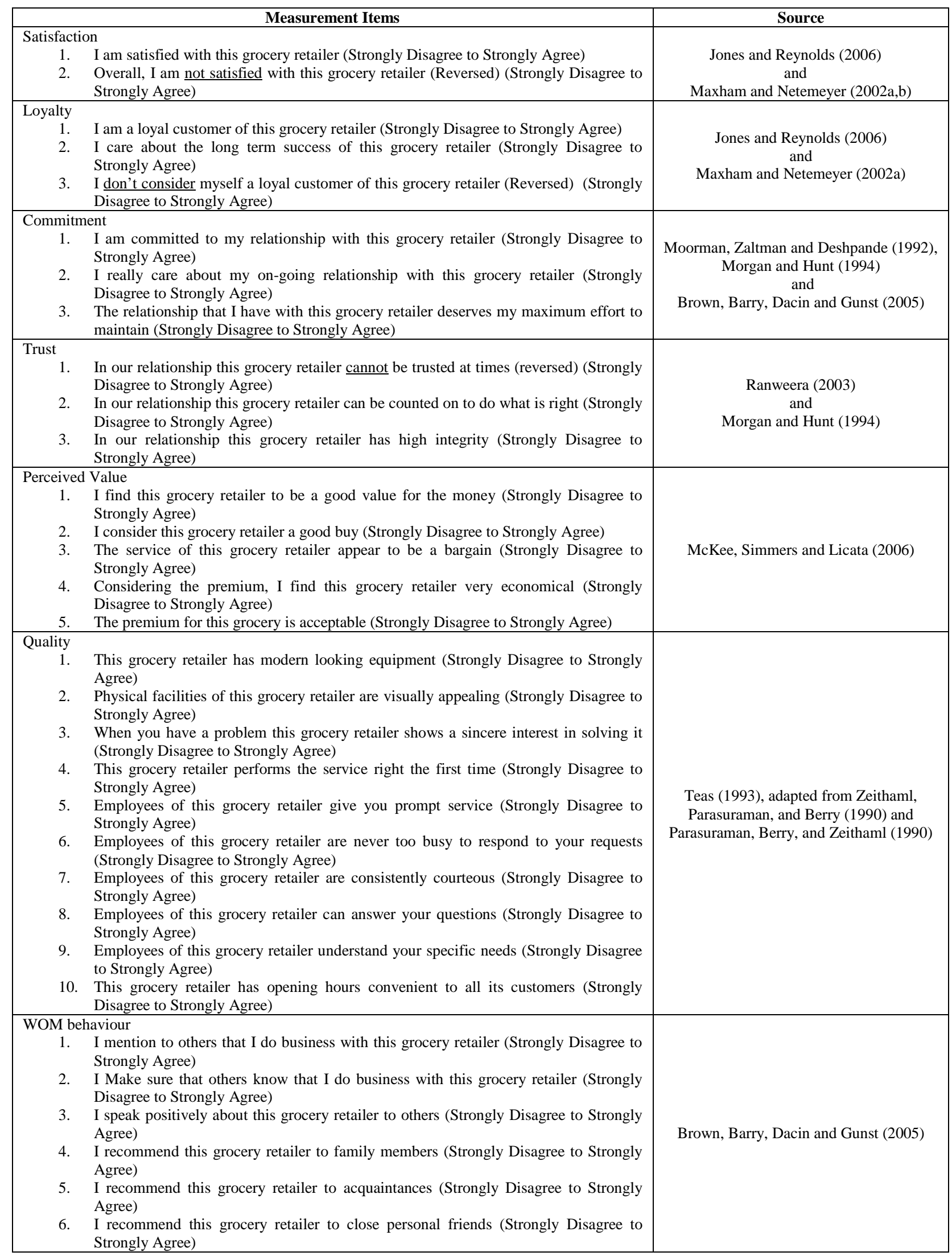




\section{Sample and Data Collection}

Each of the 25 branches of a multiple grocery retailer in Tehran was manually assigned to into one of 3 categories on the basis of the type of location and 3 branches were randomly chosen from each category, giving a total of 9 branches which were then used as sample points. The selected branches were, therefore, distributed across different areas of Tehran and different types of retail location, in order to achieve representative coverage of the retailer's customer base. Data were collected at each sample point over a two week period on weekdays, weekends and at a range of times in order to provide representative coverage of trading conditions. At each sample point, female shoppers were selected randomly resulting in a total sample of 215. The shoppers were invited to participate in the survey and then given an explanatory letter and the survey instrument to complete there and then. Self-completion minimized response bias resulting from interviewer effects.

\section{Analysis}

Hypothesis testing was conducted using bivariate correlation analysis, which measured the strength and significance of the relationship between WOM and each of the antecedent variables. Having examined the direct effect of each antecedent on WOM, we then used multiple regression to model the combined effect of the antecedents on WOM, and to estimate their overall, and individual, explanatory power. Further analysis was conducted via one-way ANOVA tests; specifically we examined the relationships between all constructs in the conceptual model and two key shopper characteristics - frequency of shopping at Sharvand and proportion of overall grocery shopping expenditure allocated to Sharvand.

\section{Results and Discussion}

Tables 2-9 present the demographic and shopper profiles of the sample. Over $60 \%$ of the sample comprised women aged 25-44, and the sample was correspondingly light in terms of younger and older shoppers. The majority of respondents had a university degree and was from middle income households of 4 people or fewer. $80 \%$ of the sample had been shopping for groceries at Sharvand for 4 years or longer, suggesting loyalty to the retailer, but most also shopped for groceries elsewhere. Table 8 shows that almost $60 \%$ of the sample shopped elsewhere for groceries at least once a week, and the share of grocery expenditure data (Table 9) reinforced the finding that few female grocery shoppers were solely loyal to Sharvand. Table 10 provides information on the source of WOM recommendation, showing that personal friends were the largest single source of WOM, but were outstripped by family when mothers and other family members were combined. 
Table 2: Age Profile

\begin{tabular}{|c|c|c|c|}
\hline Age & Frequency & Percent & Cumulative Percent \\
\hline Under 18 & 2 & 1.0 & 1.0 \\
\hline $18-24$ & 28 & 13.3 & 14.3 \\
\hline $25-34$ & 84 & 40.2 & 54.5 \\
\hline $35-44$ & 44 & 21.1 & 75.6 \\
\hline $45-54$ & 34 & 16.3 & 91.9 \\
\hline Over 55 & 17 & 8.1 & 100.0 \\
\hline
\end{tabular}

Table 3: Educational Profile

\begin{tabular}{|c|c|c|c|}
\hline Education & Frequency & Valid Percent & $\begin{array}{c}\text { Cumulative } \\
\text { Percent }\end{array}$ \\
\hline A/O level and below & 78 & 37.5 & 37.5 \\
\hline Undergraduate & 92 & 44.2 & 81.7 \\
\hline Postgraduate & 38 & 18.3 & 100.0 \\
\hline
\end{tabular}

Table 4: Income Profile

\begin{tabular}{|c|c|c|c|}
\hline Monthly Household Income & Frequency & Percent & $\begin{array}{c}\text { Cumulative } \\
\text { Percent }\end{array}$ \\
\hline Less than 500000T & 25 & 13.2 & 13.2 \\
\hline \hline 500001T-1000000T & 89 & 46.8 & 60.0 \\
\hline \hline 1000001T-2000000T & 51 & 26.8 & 86.8 \\
\hline \hline 2000001T-5000000T & 18 & 9.5 & 96.3 \\
\hline \hline More than 5000000T & 7 & 3.7 & 100.0 \\
\hline \hline
\end{tabular}

Table 5: Family Size

\begin{tabular}{|c|c|c|c|}
\hline Family Size & Frequency & Percent & Cumulative Percent \\
\hline 1-2 person & 52 & 25.5 & 25.5 \\
\hline 3-4 person & 124 & 60.8 & 86.3 \\
\hline 5 and above 5 person & 28 & 13.7 & 100.0 \\
\hline
\end{tabular}


Table 6: Length of Time Shopped at Shahrvand

\begin{tabular}{|c|c|c|c|}
\hline Length of Time & Frequency & Percent & $\begin{array}{c}\text { Cumulative } \\
\text { Percent }\end{array}$ \\
\hline $1-3$ years & 36 & 19.8 & 19.8 \\
\hline 4-6 years & 55 & 30.2 & 50.0 \\
\hline 7-9 years & 15 & 8.2 & 58.2 \\
\hline 10 years and above & 76 & 41.8 & 100.0 \\
\hline
\end{tabular}

Table 7: Frequency of Purchase from Shahrvand

\begin{tabular}{|l|l|l|l|}
\hline Frequency of Purchase & Frequency & Percent & $\begin{array}{l}\text { lumulative } \\
\text { Percent }\end{array}$ \\
\hline 3-7 days a week & 26 & 12.8 & 12.8 \\
\hline Once a week & 36 & 17.6 & 30.4 \\
\hline $1-3$ times a month & 71 & 34.8 & 65.2 \\
\hline Less than once a month & 71 & 34.8 & 100.0 \\
\hline Total & 204 & 100.0 & \\
\hline
\end{tabular}

Table 8: Frequency of Purchase from Other Grocery Retailers or Supermarkets

\begin{tabular}{|l|l|l|l|}
\hline Frequency of Purchase & Frequency & Percent & $\begin{array}{l}\text { Percent } \\
\text { 3-7 days a week }\end{array}$ \\
\hline Once a week & 53 & 26.6 & 26.6 \\
\hline $1-3$ times a month & 65 & 32.7 & 59.3 \\
\hline Less than once a month & 35 & 17.6 & 76.9 \\
\hline Total & 46 & 23.1 & 100.0 \\
\hline
\end{tabular}

Table 9: Percentage of Total Grocery Expenditure Allocated to Shahrvand

\begin{tabular}{|l|l|l|l|}
\hline Percentage of Expenditure & Frequency & Percent & Cumulative Percent \\
\hline $1 \%-20 \%$ & 42 & 22.7 & 22.7 \\
\hline $21 \%-40 \%$ & 35 & 19.0 & 41.7 \\
\hline $41 \%-60 \%$ & 49 & 26.5 & 68.2 \\
\hline $61 \%-80 \%$ & 36 & 19.4 & 87.6 \\
\hline $81 \%-100 \%$ & 23 & 12.4 & 100.0 \\
\hline Total & 185 & 100.0 & \\
\hline
\end{tabular}


Table 10: Source of Shahrvand Recommendation

\begin{tabular}{|l|l|l|l|}
\hline Source of Recommendation & Frequency & Percent & Cumulative Percent \\
\hline Personal Friends & 21 & 30.4 & 30.4 \\
\hline Acquaintances & 19 & 27.5 & 57.9 \\
\hline Other Family members & 16 & 23.2 & 81.1 \\
\hline Mother & 13 & 18.9 & 100 \\
\hline Total & 69 & 100 & \\
\hline
\end{tabular}

Moving to the testing of the conceptual model, it can be seen that the internal reliability of all measures is acceptable $(\alpha \geq .7)$ as shown in Table 11 .

Table 11: Scale Reliability

\begin{tabular}{|c|c|c|c|c|}
\hline \multicolumn{5}{|c|}{ Reliability } \\
\hline \multirow{2}{*}{ Construct } & \multirow{2}{*}{ Number of items } & \multirow{2}{*}{ Cronbach's Alpha (measured in this study) } & \multicolumn{2}{|l|}{ Previous studies } \\
\hline & & & Source/adapted from & Cronbach's Alpha \\
\hline Satisfaction & 2 & 0.7 & Jones and Reynolds (2006)/Maxham and Netemeyer (2002a,b) & 0.92 \\
\hline Loyalty & 3 & 0.798 & Jones and Reynolds (2006)/Maxham and Netemeyer (2002a) & 0.9 \\
\hline Commitment & 3 & 0.885 & Brown, Barry,Dacin and Gunst(205) & 0.94 \\
\hline Trust & 3 & 0.705 & Ranweera (2003)/Morgan and Hunt (1994) & 0.947 \\
\hline Perceived Value & 5 & 0.91 & McKee, Simmers and Licata, J. (2006), & 0.94 \\
\hline Quality & 10 & 0.897 & Teas (1993) & 0.92 \\
\hline WOM & 6 & 0.938 & Brown, Barry,Dacin and Gunst(205) & 0.95 \\
\hline
\end{tabular}

The direct effect of each of the constructs on WOM is examined through bivariate correlation analysis, the results of which reveal that there is a significant positive relationship between all of the antecedents and WOM (Table 12) and all the antecedents have large effects on WOM initiation. The results of the correlation analysis suggest that all hypotheses can be retained. These findings are in agreement with those of De Matos and Rossi (2008). Furthermore, commitment has the highest correlation with WOM in line with the findings of De Matos and Rossi (2008), Brown et al. (2005), Fullerton (2003), and Lacey, Shuh and Morgan (2007). 
Table 12: Strength of Correlations between WOM and Hypothesised Antecedents

\begin{tabular}{|l|c|}
\hline Variables & Correlation with WOM \\
\hline Commitment & $0.729^{* * *}$ \\
\hline \hline Perceived value & $0.690^{* * *}$ \\
\hline \hline Loyalty & $0.677^{* * *}$ \\
\hline \hline Trust & $0.655^{* * *}$ \\
\hline \hline Quality & $0.551^{* * *}$ \\
\hline \hline Satisfaction & $0.549^{* * *}$ \\
\hline
\end{tabular}

Multiple regression analysis, with WOM as the dependent variable, allowed us to conduct further examination of the effect of the antecedents on WOM. The initial regression model included all the antecedents in the conceptual model as independent variables and was found to be significant $(\mathrm{P}=.000)$ in predicting WOM. Although commitment, perceived value, loyalty, quality and satisfaction were found to be significant predictors of WOM, $(\mathrm{P}=.000)$ trustwas not found to be a significant predictor $(\mathrm{P}=.000)$.

As a result, the regression analysis was re-run removing trust, and the resultant model (Tables13-15) was still found to be significant overall $(\mathrm{P}=.000)$. All explanatory variables were found to be significant, positive predictors of WOM. The $\mathrm{R}^{2}$ value of 0.758 indicates a very good fit of the model, and the value of the Adjusted $R^{2}$ is very close to that of the $R^{2}$, thus raising no concern regarding overfitting. The $\mathrm{F}$ value of 119.771 is highly significant.

Table 13: Regression Analysis - final model summary

\begin{tabular}{|l|l|l|l|l|}
\hline Model & R & R Square & Adjusted R Square & Std. Error of the Estimate \\
\hline 1 & $.871^{\mathrm{a}}$ & .758 & .752 & .598 \\
\hline
\end{tabular}

a. Predictors: (Constant), Total Quality, Total Satisfaction, Total Commitment, Total Perceived Value, Total Loyalty

Table 14: Regression analysis - final model ANOVA ${ }^{b}$

\begin{tabular}{|ll|l|l|l|l|l|l|}
\hline Model & Sum of Squares & Df & Mean Square & F & Sig. \\
\hline 1 & Regression & 214.362 & 5 & 42.872 & 119.771 & $.000^{\mathrm{a}}$ \\
& $\begin{array}{l}\text { Residual } \\
\text { Total }\end{array}$ & 68.369 & 191 & .358 & & & \\
& 282.731 & 196 & & & \\
\hline
\end{tabular}


Table 15: Regression Coefficients- Final Model

\begin{tabular}{|c|c|c|c|c|c|c|}
\hline \multicolumn{7}{|c|}{ Coefficients $^{\mathrm{a}}$} \\
\hline \multirow{2}{*}{\multicolumn{2}{|c|}{ Model }} & \multicolumn{2}{|c|}{ Unstandardized Coefficients } & \multirow{2}{*}{$\begin{array}{c}\begin{array}{c}\text { Standardized } \\
\text { Coefficients }\end{array} \\
\text { Beta }\end{array}$} & \multirow[b]{2}{*}{$t$} & \multirow[b]{2}{*}{ Sig. } \\
\hline & & $B$ & Std. Error & & & \\
\hline \multirow[t]{6}{*}{1} & (Constant) & -.042 & .286 & & -.148 & .882 \\
\hline & Total_Satisfaction & .119 & .052 & .106 & 2.284 & .023 \\
\hline & Total_loyalty & .143 & .056 & .152 & 2.537 & .012 \\
\hline & Total_commitment & .326 & .054 & .367 & 6.049 & .000 \\
\hline & Total_Perceivedvalue & .238 & .043 & .270 & 5.475 & .000 \\
\hline & Total_Quality & .223 & .056 & .174 & 3.977 & .000 \\
\hline
\end{tabular}

a. Dependent Variable: Total_Wom

An examination of the standardized beta coefficients shown in Table 15 indicates that commitment makes the strongest statistical contribution to explaining WOM (standardized beta coefficient of .367), suggesting that customer commitment to the grocery retailer has the largest influence on WOM. In contrast, satisfaction makes the weakest statistical contribution to explaining WOM (standardized beta coefficient of .106) suggesting that customers' satisfaction with the grocery retailer has the least influence on WOM initiation.

Having tested the conceptual model, we then investigated, using a series of one-way ANOVA tests, whether there are significant differences in mean values of WOM and of the antecedent variables by shopper characteristics (frequency, expenditure). The highest levels of satisfaction, commitment, loyalty, trust, perceived value, quality and WOM are found among those shopping at the grocery retailer most frequently (3-7 days a week) while the lowest levels of satisfaction are found among the least frequent shoppers (less than once a month). A similar pattern is found for expenditure with the highest levels of satisfaction, commitment, loyalty, trust, perceived value, quality and WOM being found among those allocating the highest proportion of their monthly grocery expenditure to the grocery retailer (80-100\%). All differences are significant $(\mathrm{P}=.000)$. These findings suggest that there are significant, positive relationships between measures of behavioural loyalty (shopping frequency and expenditure) and all the constructs in our conceptual model. Thus, the more frequently a shopper patronises Sharvand and the more of their grocery expenditure they allocate to the retailer, the stronger their positive attitude to the retailer and the greater their level of WOM.

\section{Conclusions and Recommendations}

Given that there is no extant research on antecedents of WOM in the Iranian grocery market, this research aims to fill this gap with a study of female Iranian shoppers. Using De Matos and Rossi's (2008) conceptual model, we find satisfaction, loyalty, quality, commitment and perceived value to be significant antecedents of WOM with commitment, perceived value and loyalty together explaining $70 \%$ of the variation in WOM. However, although we found trust to be significantly and positively correlated with WOM, we did not find trust to make a significant contribution to explaining WOM as a result of multi-collinearity. Our research, however, broadly supports the conceptual model of De Matos and Rossi (2008) and their finding that commitment is the most significant single predictor of WOM. From a managerial perspective, therefore, it is essential for the managers of Iranian grocery retailers to try to 
increase the levels of all these variables, especially commitment, in order to initiate WOM. This may be achieved, for example, by keeping customers informed about products, services and offers, by interactions with customers through marketing communications and in-store activities, and by establishing a strong brand identity.

Furthermore the strong relationship between customers' perceived value and WOM initiation suggests the importance of improving customers' perceptions of the value which they have received, for example through the use of customer testimonials and of price guarantees. Additionally, given the significant positive effect of customer's loyalty on WOM initiation, it is important for managers to increase customer loyalty through, for example, loyalty schemes.

Our results also indicate that increasing the frequency of shopping and the proportion of grocery expenditure allocated to a store will have strong positive effects on female shoppers' satisfaction, loyalty, quality, commitment, perceived value and WOM initiation. Finally, our findings show that satisfaction is the weakest predictor of WOM, and therefore it is dangerous for grocery retail managers to rely on customer satisfaction metrics as indicators of WOM initiation.

\section{Limitations and Further Research}

Although the results of this study expand our understanding of factors affecting the initiation of WOM among Iranian female grocery shoppers, our research has certain limitations. Firstly, only factors affecting initiation of positive WOM behavior have been examined. Consequently, investigation of factors affecting the initiation of negative WOM as well as positive WOM is suggested for future studies. Secondly, our research sample is chosen from female customers of one multiple grocery retailer and customers of other grocery retailers were not sampled. Consequently, future investigations should be conducted on customers of other Iranian grocery retailers. Thirdly, this research examined female customers of the grocery retailer only and male customers were not included. Therefore it is recommended that further research includes men as well as women. Fourthly, as the present research only focuses on residents of Tehran, further research covering other cities is also recommended. Finally, in adopting De Matos and Rossi's (2008) model as the basis of our research, we were unable to adopt a hierarchical conceptualization of the relationships between WOM and its antecedents. This could be the focus of further research, using structural equation modeling to test a hierarchical model. 


\section{References}

Arnett, D.B., German, S.D. and Hunt, S.D. (2003) 'The identity salience model of relationship marketing successes: the case of nonprofit marketing', Journal of Marketing, Vol. 67 No. 2, pp. 89-105.

Ashtiani, P.G. and Iranmanesh, A. (2012) 'New approach to study of factors affecting adoption of electroncic banking services with emphasis on the role of positive word of mouth', African Journal of Business Management, Vol. 6 No. 11, pp. 4328-4335.

Bloemer, J. de Ruyter, K. and Wetzels, M. (1999) 'Linking perceived service quality and service loyalty: a multi-dimensional perspective’, European Journal of Marketing, Vol. 33 No. 11/12, pp. 1082-1106.

Boulding, W., Kalra, A., Staelin, R. and Zeithaml, V.A. (1993) 'A dynamic process model of service quality: from expectations to behavioral intentions’, Journal of Marketing, Vol. 55 No. 10, pp. 1-10.

Brown, T., Barry, T., Dacin, P. and Gunst, R. (2005) 'Spreading the word: investigating antecedents of consumers' positive word of mouth intentions and behaviors in a retailing context', Journal of the Academy of Marketing Science, Vol. 33 No. 2, pp. 123-138.

Carpenter, J.M. and Fairhurst, A. (2005) 'Consumer shopping value, satisfaction and loyalty for retail apparel brands', Journal of Fashion Marketing and Management, Vol. 9 No. 3, pp. 256-269.

Cheung, C.M.K. and Thadani, D.R. (2012) 'The impact of electronic word-of-mouth communication: A literature analysis and integrative model’, Decision Support Systems, Vol. 54 No. 1, pp. 461-470.

De Matos, C.A. and Rossi, C.A.V. (2008) 'Word-of-mouth communications in marketing: a metaanalytic review of antecedents and moderators', Journal of the Academy of Marketing Science, Vol. 36 No. 4, pp. 578-596.

Dick, A.S. and Basu, K. (1994) 'Customer loyalty: towards an integrated conceptual framework', Journal of the Academy of Marketing Science, Vol. 22 No. 2, pp. 99-113.

Ennew, C.T., Banerjee, A.K. and Li, D. (2000) 'Managing word of mouth communication: empirical evidence from India’, International Journal of Bank Marketing, Vol. 18 No. 2, pp. 75-83.

Euromonitor (2013) Retailing in Iran available at: http://www.euromonitor.com/retailing-iniran/report (accessed 26 January 2014).

Fullerton, G. (2003) 'When does commitment lead to loyalty?', Journal of Service Research, Vol. 5 No. 4, pp. 333-344.

Godes, D. and Mayzlin, D. (2004) 'Using online conversations to study word-of-mouth communication', Marketing Science, Vol. 23 No. 4, pp. 545-560.

Harrison-Walker, L.J. (2001) 'The measurement of word-of-mouth communication and an investigation of service quality and customer commitment as potential antecedents', Journal of Service Research, Vol. 4 No. 1, pp. 60-75.

Hartline, M.D. and Jones, K.C. (1996) 'Employee performance cues in a hotel service environment: influence on perceived service quality, value and word of mouth intentions', Journal of Business Research, Vol. 35 No. 3, pp. 207-215.

Heitmann, M., Lehmann, D.R. and Hermann, A. (2007) 'Choice goal attainment and decision and consumption satisfaction’, Journal of Marketing Research, Vol. 44, No. 2, pp. 234-250.

Hennig-Thurau, T., Gwinner, K.P. and Gremler, D.D. (2002) 'Electronic word-of-mouth via consumer-opinion platforms: what motivates consumers to articulate themselves on the internet?, Journal of Interactive Marketing, Vol. 18 No. 1, pp. 38-52.

Higie, R.A., Feick, L.F. and Price, L.L. (1987) 'Types and amount of word-of-mouth communications about retailing', Journal of Retailing, Vol. 63 No. 3, pp. 260-278.

Hyperstar Iran (no date) Available at: http://www.hyperstariran.com (accessed 26 January 2014).

Jalilvand, M.R., Esfahani, S.S. and Samiei, N. (2011) 'Electronic word-of-mouth: challenges and opportunities’, Procedia Computer Science, Vol. 3, pp. 42-46. 
Jalilvand, M.R. and Samiei, N. (2012a) 'The effect of electronic word of mouth on brand image and purchase intention’, Marketing Intelligence and Planning, Vol. 30 No. 4, pp. 1-11.

Jalilvand, M.R. and Samiei, N. (2012b) 'The effect of word of mouth on inbound tourists' decision for travelling to Islamic destinations (the case of Isfahan as a tourist destination in Iran), Journal of Islamic Marketing, Vol. 3 No. 1, pp. 12-21.

Jones, T.O. and Sasser. W.E. (1995) 'Why satisfied customers defect', Harvard Business Review, Vol, 73 No. 6, pp. 88-99.

Keller, G. (2009) 'Tehran hypermarket opens without Carrefour name.' The Daily Star, 26 September. Available at: http://www.dailystar.com.lb/Business/Middle-East/2009/Sep26/81230-tehran-hypermarket-opens-without-carrefour-name.ashx\#axzz2q0nzHaFb (accessed 26 January 2014).

Kim, T., Kim, W.E. and Kim, H-B. (2009) 'The effects of perceived justice on recovery satisafaction, trust, word-of-mouth, and revisit intention in upscale hotels’, Tourism Management, Vol. 30 No. 1, pp. 51-62.

Kimmel and Kitchen (2014) 'Word of Mouth Reconsidered: Facts, Fallcies and Future Directions', 13th International Marketing Trends Conference, Venice, 24th - 25th January 2014 available at: http://www.marketing-trends-congress.com/archives/2014/pages/PDF/255.pdf (accessed 4 December 2014).

Lacey, R., Shuh, J. and Morgan, R.M. (2007) 'Differential effects of preferential treatment levels on relational outcomes’, Journal of Service Research, Vol. 9 No. 3, pp. 241-256.

Lee, J.A.L.M., More, S.J. and Cotiw-an, B.S. (1999) 'Problems translating a questionnaire in a crosscultural setting', Preventative Veterinary Medicine, Vol. 41, pp. 187-194.

Lee, C.K., Yoon, Y.S. and Lee, S.K. (2007) 'Investigating the relationships among perceived value, satisfaction and recommendations: The case of the Korean DMZ', Vol. 28 No. 1, pp. 204214.

Magnold, G.W. (1987) 'Use of commercial sources of information in the purchase of professional services: what the literature tells us', Journal of Professional Services Marketing, Vol. 3 No. 1/2, pp. 5-17.

McKee, D., Simmers, C.S. and Licata, J. (2006) 'Customer self-efficacy and response to service', Journal of Service Research, Vol. 8 No. 3, pp. 207-220.

Mohammadian, M. and Shafiha, R. (2008) 'An investigation of factors influencing brand equity from consumer’s perspective’, J. Marketing Management, (in Persian), Vol. 3 No. 4, pp. 41-60.

Mosavei, S.A. and Ghaedi, M. (2011) 'A survey on the relationships between customer satisfaction, image, trust and customer advocacy behavior', African Journal of Business Management, Vol. 6 No. 8, pp. 2897-2910.

Murray, K.B. (1991) 'A test of services marketing theory: consumer information acquisition activities', Journal of Marketing, Vol. 55 No. 1, pp. 10-25.

Ranaweera, C. and Prabhu, J. (2003) 'On the relative importance of customer satisfaction and trust as determinants of customer retention and positive word of mouth', Journal of Targeting, Measurement and Analysis for Marketing, Vol. 12 No. 1, pp. 82-90.

Reynolds, K.E. and Beatty, S.E. (1999) 'Customer benefits and company consequences of customersalesperson relationships in retailing', Journal of Retailing, Vol. 75 No. 1, pp. 11-32.

Shirsavar, H.A., Gilaninia, S. and Almani, A.M. (2012) 'A study of factors influencing positive word of mouth in the Iranian banking industry', Middle East Journal of Scientific Research, Vol. 11 No. 4, pp. 454-460.

Sichtmann, C. (2007) 'An analysis of antecedents and consequences of trust in a corporate brand', European Journal of Marketing, Vol. 41 No. 9/10, pp. 999-1015.

Sirdeshmukh, D., Singh, J. and Sabol, B. (2002) 'Consumer trust, value and loyalty in relational exchanges’, Journal of Marketing, Vol. 66 No. 1, pp. 15-37. 
Urbany, J.E., Dickson, P.R. and Kalapurakal, K. (1996) 'Price search in the retail grocery market', Journal of Marketing, Vol. 60 No. 2, pp. 91-104.

Wangenheim, F.V. (2005) 'Postswitching negative word of mouth', Journal of Service Research, Vol. 8 No. 1, pp. 67-78.

Wangenheim, F.V. and Bayón, T. (2007) 'The chain from customer satisfaction via word-of-mouth referrals to new customer acquisition', Journal of the Academy of Marketing Science, Vol. 35 No. 2, pp. 233-249.

Westbrook, R.A. (1987) 'Product/consumption-based affective responses and postpurchase processes’, Journal of Marketing Research, Vol. 24 No. 3, pp. 258-270.

Zeithaml, V.A., Berry, L.L. and Parasuraman, A. (1996) 'The behavioural consequences of service quality’, Journal of Marketing, Vol. 60 No. 2, pp. 31-47. 